\title{
Taxation Effects on Economic Activity in Pakistan
}

\author{
Saima Saqib ${ }^{1}$, Dr. Tariq Ali ${ }^{2}$, Muhammad Faraz Riaz ${ }^{2, *}$, Dr. Sofia Anwar ${ }^{2}$, Amir Aslam ${ }^{2}$ \\ ${ }^{1}$ Department of Economics, Government College University for Women Faisalabad, Punjab-Pakistan \\ ${ }^{2}$ Department of Economics, Government College University Faisalabad, Punjab-Pakistan \\ *Corresponding author: fraz.riaz@gmail.com
}

Received October 29, 2014; Revised November 18, 2014; Accepted December 05, 2014

\begin{abstract}
This paper analyzes the effects of taxes on economic activity in Pakistan. Economic activity is examined through real GDP, consumption and investment, and for each from the said proxies a different econometric model is developed for analysis. Tax to GDP ratio for growth model, sales tax for consumption model and income tax for investment model are used. Real GDP, total investment and household consumption expenditures are used as dependent variables. Time series data from 1973 to 2010 are used for empirical analysis. Keeping in view the alternate order of integration of different variables ARDL approach to co-integration for growth model is utilized. While Johansen's co-integration technique is used in investment and consumption models as all the variables involved in these said models are found to be I(0). We found negative effects of tax to GDP ratio on real GDP, negative effects of income tax on investment and negative effects of sales tax on household consumption expenditures. Finally, we concluded that the present level of taxation in Pakistan needs to be revised carefully as this has negative effects on economic activity in Pakistan.
\end{abstract}

Keywords: growth, investment, consumption, ARDL, ecm term

Cite This Article: Saima Saqib, Dr. Tariq Ali, Muhammad Faraz Riaz, Dr. Sofia Anwar, and Amir Aslam, "Taxation Effects on Economic Activity in Pakistan." Journal of Finance and Economics, vol. 2, no. 6 (2014): 215-219. doi: 10.12691/jfe-2-6-3.

\section{Introduction}

Taxes are the cost of living in a civilized society that people have to pay, vital for economic development and planning. Tax is also an enforced levy imposed on commodities, firms, individuals, and communities by the government. But the feature of compulsory levy is usually destabilized because people never like this public responsibility (Ebiringa and Yadirichukwu, 2012). Taxation has key role in developmental policies. It is further interlinked with other policy areas. Taxation forms good governance to formalize the economy for spurring growth; provides funds for the government to build the infrastructure; creates a healthy atmosphere to promote business and international trade, shapes the way for government activities and also plays a crucial role in mobilization of domestic resources. So, taxation has diverse effects on aggregate economic activity, where economic activity means growth in consumption, investment, employment and finally growth of GDP (Lescaroux and Mignon, 2008). Gross domestic product (GDP) is the most widely used measure of economic activity, but it is criticized that GDP does not include some economic activities inside the production boundary (Vanoli et al 2005). In present study we used GDP growth, consumption growth and investment growth to measure economic activity.

Taxes have different effects on various economic activities. Taxes affect individuals' decisions to save, the decision of firms to produce, invest, create jobs, innovate investment in human capital and supply of labour. Taxation has both positive and negative effects on GDP i.e. income taxes have strong negative effects on economic growth (Poulson and Kaplan 2008); Customs and excise duties inversely affect economic growth (Ebiringa and Yadirichukwu, 2012). Corporate taxes are more harmful for economic growth than other taxes. As higher corporate tax rates have multiple effects on entire economy i.e. it affects entrepreneur decisions to invest that effects employment level as well as production and inflation rate (Lee and Gordon, 2005). Statutory corporate tax rates are related with lower per capita income in all countries under analysis over time (Dahlby, 2012).

Distortions to choice and disincentive effects cause negative effects whereas the expenditures directly financed by taxation cause the positive effects (Myles, 2007). Some studies present positive relationship between tax and economic growth (Mashkoor et al 2010; Ioan and Constanti, 2010). Padovano and Galli (2001) analyzed the relationship between tax rates and economic growth and also found negative effects of marginal income tax rates on economic growth. Koester and Kormendi (1989) analysed effects of taxation on aggregate activity and economic growth and found marginal tax rate has significant negative effects on economic activity.

In the case of investment incentives, high tax rates depress the rate of investment, or slow down the growth in the capital stock through high corporate income and individual income tax rates, high capital income tax rates, high payroll tax rates and high tax rates on production. 
Tax policy can also distort the investment from high tax sector to the low tax sector with low efficiency by affecting the marginal productivity of the capital (Harberger, 1966). Investment decisions of firms do not depend on effective average tax rates (EATR) but do depend on effective marginal tax rates (EMTR) when these firms are financially constrained. Gupta (2012) analysed the economic impacts of income tax on saving and investment. He concluded that with low income tax people has more disposable income that can be used for saving and investment. Schreiber et al., (2002) analysed effects of taxation on financing decisions and investment. Decision makers may take wrong decisions by ignoring complicated tax features and rely on just statutory tax rates. They concluded that effective tax rates are useful for both business managers and policy makers to access the investment tax burden.

In the case of consumption taxes have adverse effects on house hold consumption as well as aggregate consumption. An increase in taxes on consumption through increase in VAT rates reduces the consumption in short-run and a larger reduction in the long-run (Alm and Asmaa, 2013). Similarly VAT have different effects on consumption behaviour depending on the after and before the time of implementing the tax rates. Before implementing the VAT rate consumption is increased after implementing its immediate response is negative, then with the passage of time consumption is gradually increased (Miki, 2011). Richter (2000) described different types of consumption taxes in Jamaica i.e. value-added tax as general consumption tax (GCT) and several excise duties as special consumption tax (SCT). Garner (2005) explored the macroeconomic effects of replacing the current income tax based federal tax system with consumption tax. He found that that taxing income rather than consumption is higher tax burden for households. Parker (1999) explored the reaction of household consumption in response to predictable change in payroll tax rates in USA. They concluded that if the expected change in tax rates influenced the consumption behaviour, then the fiscal stabilization might affect consumption.

Like many developing countries taxation in Pakistan also creates a major part of government income. In Pakistan 70 types of taxes are levied that are divided into two broad categories i.e. direct taxes and indirect taxes. Pakistan has an inefficient tax system with a narrow tax base, administrative weaknesses and massive tax evasion (Inam and Khan, 2008). Agriculture is a major sector of Pakistan's economy but the share of this sector in total tax revenues is just $1 \%$, whereas industrial and services sectors contribute $63 \%$ and $26 \%$ in total tax revenues, respectively ( Economic Survey of Pakistan, 2010-11). During the last decade tax to GDP ratio in Pakistan varied from 8.6\% to 9.8\% (Economic Survey of Pakistan, 201112). An effective tax system is essential for raising sufficient tax revenue. Azeem et al., (2013) examined the relationship between tax rates and economic growth of Pakistan and found negative taxation effects on real per capita GDP, While income tax has negative effects on investment in Pakistan (Atif et al., 2012).

In the presence of such an imbalanced tax structure in Pakistan there is a need of empirical analysis of taxes that can maintain the economic activity at increased tax revenue and tax base.

Objectives

The overall goal of the study is to assess the impact of taxation on economic activity in Pakistan. This goal is achieved by following objectives:

General Objective

Analysis of taxation effects on economic activity in Pakistan.

Specific Objectives

1. Analysis of taxation effects on GDP growth.

2. Analysis of income tax effects on Investment.

3. Analysis of sales taxes on household consumption pattern.

Taxation in Pakistan is a burning and challenging issue for government and policy makers. A comprehensive analysis of taxation in Pakistan is required to upgrade a competitive tax system in order to attract foreign capital, modern technologies and specialized work, which result in prosperity and faster economic growth. This paper is an attempt to analyze the effects of Taxes on Economy of Pakistan.

\section{Methodology}

We used time series data from 1973 to 2010 for empirical analysis. Three models are constructed to check the effects of tax structure on different economics activities in Pakistan.

Table 1. Models Specification

\begin{tabular}{|l|l|l|}
\hline Models & Functional Forms & Econometric form \\
\hline Growth Model & $\begin{array}{l}\text { GDP }=f(\text { Investment, Tax to GDP ratio, Public Services, Inflation, } \\
\text { Labor Force })\end{array}$ & $\begin{array}{l}\mathrm{LGDP}=\beta_{0}+\beta_{1} \mathrm{LINV}+\beta_{2} \mathrm{LLF}+\beta_{3} \mathrm{LATAX}+ \\
\beta_{5} \mathrm{LPS}+\varepsilon_{\mathrm{t}}\end{array}$ \\
\hline Investment Model & Investment=f(Income tax, GDP, Rate of interest, Inflation) & $\mathrm{LINV}=\beta_{0}+\beta_{1} \mathrm{LITax}+\beta_{2} \mathrm{LGDP}+\beta_{3} \mathrm{LCPI}+\beta_{4} \mathrm{RR}+\varepsilon$ \\
\hline Consumption Model & $\begin{array}{l}\text { Consumption }=\mathrm{f}(\text { Disposable income, Sales Tax, Rate of interest, } \\
\text { Inflation) }\end{array}$ & LHCEXP $=\beta_{0}+\beta_{1} \mathrm{Lyd}+\beta_{2} \mathrm{LST}+\beta_{3} \mathrm{RR}+\beta_{4} \mathrm{LCPI}+\varepsilon_{\mathrm{t}}$ \\
\hline
\end{tabular}

The above table presented the basic functional and econometric forms of models.

Description and data source of variables used in models is given in the following Table 2 .

Empirical analysis is done by uni-variate and multivariate analysis. In univariate analysis the stationarity of the data is checked through Augmented Dickey Fuller test. In multivariate analysis cointegration test is used to estimate the long-run relationship and ECM (Error Correction Model) for short run effects. We used
ARDL (Autoregressive Distributed lag) co-integration for growth model and Johansen's co-integration for both consumption and investment models.

\section{Results and Discussion}

Most of financial and economic series show trending behaviour. So, there is need to check the stationarity level of these series to make the appropriate use of data. Augmented 
Dickey Fuller test is used to check the stationarity of data. The ADF test results are presented in the Table 3.

Table 2. Description of Variables

\begin{tabular}{|c|c|c|c|}
\hline Variables & Symbol & Description & Data Source \\
\hline GDP & GDP & Gross Domestic Product in real form on base of 2001. & Federal Bureau of Statistics \\
\hline Investment & INV & Private Investment & Federal Bureau of Statistics \\
\hline Labor Force & LF & Employed Labor Force. & Economic Surveys of various years. \\
\hline Tax to GDP ratio & Tax_GDP & Total tax revenue divided by GDP & Federal Bureau of Revenue \\
\hline Public services & PS & $\begin{array}{l}\text { Sum of three basic public services (expenditures on Education+ } \\
\text { expenditures on Health+ expenditure on Defence). }\end{array}$ & Federal Bureau of Statistics \\
\hline Inflation & CPI & Inflation is measure by Consumers Price Index on base of 2001. & Federal Bureau of Statistics \\
\hline Rate of interest & $\mathrm{RR}$ & $\begin{array}{l}\text { Real rate of interest (Bank rate for investment model and money } \\
\text { market rate for consumption model). }\end{array}$ & International Finance Statistics. \\
\hline Income tax & ITax & $\begin{array}{l}\text { Income Tax levied on the income of Individuals, Association of } \\
\text { Persons, and Companies. }\end{array}$ & Federal Bureau of Revenue \\
\hline Consumption & HCEXP & Consumption is measured by Household Consumption Expenditures. & World Development Indicator. \\
\hline Disposable income & Yd & It is after tax income of individuals (Yd= GDP-direct taxes). & $\begin{array}{l}\text { Federal Bureau of Statistics \& Federal } \\
\text { Bureau of Revenue }\end{array}$ \\
\hline Sales Tax & $\mathrm{ST}$ & Sales tax is & Federal Bureau of Revenue \\
\hline
\end{tabular}

Table 3. ADF test results

\begin{tabular}{|l|l|l|l|l|l|l|l|}
\hline Variables & ADF statistics & Critical values & Stationarity & Variables & ADF statistics & Critical values & Stationarity \\
\hline LGDP & -5.642 & -3.54 & $1^{\text {st }}$ & RR(bank rate) & -3.928 & -3.54 & $1^{\text {st }}$ \\
\hline LINV & -3.739 & -3.54 & $1^{\text {st }}$ & LST & -5.340 & -3.54 & $1^{\text {st }}$ \\
\hline LPS & -4.238 & -3.54 & Level & RR(money market) & -5.064 & -3.54 & $1^{\text {st }}$ \\
\hline LTax_GDP & -4.451 & -3.54 & Level & LHCEXP & -6.321 & -3.54 & $1^{\text {st }}$ \\
\hline LLF & -4.238 & -3.54 & $1^{\text {st }}$ & LYd & -5.499 & -3.54 & $1^{\text {st }}$ \\
\hline LITAX & -5.926 & -3.54 & $1^{\text {st }}$ & LCPI & -3.767 & -3.54 & $1^{\text {st }}$ \\
\hline
\end{tabular}

Source: Author's own calculations.

ADF results indicate that all the variables are stationary at their first difference except average tax and CPI and labour force. These unit root results suggested using ARDL approach to co-integration for growth model and Johansen's co-integration for consumption and investment model.

Table 4. Estimation Results

\begin{tabular}{|l|l|l|l|}
\hline Variables & Growth Model & $\begin{array}{l}\text { Investment } \\
\text { model }\end{array}$ & $\begin{array}{l}\text { Consumption } \\
\text { Model }\end{array}$ \\
\hline $\begin{array}{l}\text { Dependent } \\
\text { variable }\end{array}$ & LGDP & LINV & LHCEXP \\
\hline C & 1.443 & 0.022 & 1.549 \\
\hline LLF & $1.091[2.88]$ & & \\
\hline LINV & $-0.002[-.0103]$ & & \\
\hline LPS & $0.164[2.042]$ & & \\
\hline LTAX_GDP & $-0.433[-2.073]$ & & \\
\hline LCPI & $0.236[2.926]$ & $-1.688[2.978]$ & $0.922[-5.470]$ \\
\hline RR & & $-0.005[3.926]$ & $-0.028[8.864]$ \\
\hline LITAX & & $-2.516[3.157]$ & \\
\hline LGDP & & $0.929[2.109]$ & \\
\hline LYD & & & $0.293[-1.762]$ \\
\hline LST & & & $-0.146[2.289]$ \\
\hline ECM & $-0.349[-4.489]$ & $-0.567[-3.435]$ & $-0.159[-2.096]$ \\
\hline $\mathbf{R}^{2}$ & 0.888 & 0.664 & 0.723 \\
\hline DW-statistic & 2.188 & 2.511 & 2.725 \\
\hline S & & &
\end{tabular}

Source: Author's own calculations.

$\mathrm{L}$ with above abbreviations indicates logarithmic form of variables and values in square brackets indicate t-values. [ $\mathrm{t}$-values].

Results in the Table 4 show the all coefficients of growth model are significant except investment that is insignificant in long-run. This insignificant relationship is due to crowding out effects in Pakistan. Literature on investment confirms the existence crowding out effects in Pakistan (Sagir and Khan, 2012). Relationship between consumers' price index and GDP is also positive i.e. 1\% increase in CPI causes $0.236 \%$ increase real GDP. Relationship between tax and real GDP is negative; it shows that $1 \%$ increase in tax to GDP ratio caused $0.433 \%$ decrease in real GDP. Our results support the results of Mashkoor et al., (2010) that associated tax to GDP ratio with real GDP for Pakistan but did not include the role of public services. Many studies also negatively relate taxes with GDP i.e. (Anastassiou and Dritsaki, 2005; Padovano and Galli, 2001; Poulson and Kaplan, 2008; Stephen, 2009). This is the one sided impact of taxation but these effects of taxation may be different when we include the effects of government expenditures in form of public spending.

Phillips and Goss (1995) found that including the public services in economic growth and business location studies decrease the size of negative effects of average tax rates. When no public services are included the effects are insignificant. We found positive relationship between public services and GDP i.e. 1\% increase in public services causes .164\% increase in real GDP. Relationship between labour force and GDP is also positive i.e. 1\% increases in employed labour force causes 1.091\% increase in real GDP. Charney (2010) also interpreted the positive effects of government spending on economic growth. Negative effects of taxes on GDP are justified as taxes affect individuals' decisions to save, the decision of firms to produce, create jobs, invest, and innovate, investment in human capital and supply of labour. 
The value of ECM term is -0.349 . This negative value of ECM term indicates that GDP converges to equilibrium. The value -0.349 means that $34 \%$ convergence in real GDP is occurring from short-run to long run equilibrium within a year for Pakistan, due to increase in tax to GDP ratio and other explanatory variables. It also indicates that GDP takes more than 6 months to converge to its equilibrium value due to effects of average tax rates and other variables.

All coefficients of investment model are significant. Relationship between investment and CPI is negative i.e. $1 \%$ increase in the CPI cause $1.688 \%$ decrease in investment. This negative relation is just because of high inflation that results in high cost of production (due to high prices of raw material) which induces investors to invest less. Iqbal and Nawaz (2009) also found negative effects of inflation on investment. Shahbaz and Rahman (2010) explored determinant of investment and found negative effects of inflation on investment. Relationship between income tax and investment is positive i.e. 1\% increase in income tax causes $2.516 \%$ increase in investment. These negative effects may be experienced due to disincentive effects that urge investors to invest less. Moreover, due to income tax, individual left with low disposable income that results in low saving and finally low investment. Income tax on income of corporations/companies results in low profits that discourage corporate investment. All these tax effects decreases total investment. Atif et al., (2012) also found negative effects of income tax on investment in Pakistan. Frank et al., (2010) found negative effects of dividend tax on investment. Gupta (2012) found that tax on individual personal income reduce incentive to work, save and invest. The relationship between real rate of interest and investment is negative i.e. 1 unit change in rate of interest cause $0.005 \%$ decrease in investment. This type of negative relation between private investment and real rate of interest is also found by (Saghir and Khan 2012). Theories on investment also defined negative relationship between investment and rate of interest. Shahbaz and Rahman (2010) explored determinant of investment and found real rate of interest has negative effects on investment. We also found positive relationship between investment and GDP i.e. 1\% increase in GDP there is $0.929 \%$ increase in investment. Shahbaz and Rahman (2010) explored determinant of investment and found positive effects of real GDP on investment. The coefficient of ECM is -0.567 which shows that $1 \%$ convergence in investment from short run to long run is occurring due to change in the income tax and other explanatory variables with in the year for Pakistan and tvalue shows that the ECM is statistically significant at 5\% level. It also indicates that investment takes more than half year converges to equilibrium.

Similarly all coefficients of consumption model are also significant. The relationship between dependent and independent variables are same as expected prior. Relationship between house hold consumption expenditures and CPI is positive; it shows that $1 \%$ increase in CPI there is $0.922 \%$ increase in house hold consumption expenditures in long-run. This relationship also observed and analyzed by Abdullah and Kalim (2009). The rationale behind this relation is this; more expenditure is required for high price level. Relationship between disposable income and consumption expenditures is positive; it shows that $1 \%$ increase in Yd caused $0.293 \%$ increase household consumption expenditures. Relationship between real rate of interest is also negative i.e. due to $1 \%$ increase in RR there is $0.028 \%$ decrease in household consumption expenditures. We can justify our result as, when rate of interest in money market is high people prefer to more invest in money market and reduce their consumption expenditures. The relationship between sales tax and consumption is also negative; i.e. $1 \%$ increase sales tax causes $0.146 \%$ decrease in household consumption expenditures. Refaqat (2003) also observed this type of sales tax effects on consumption. We can justify our result as increase in sales tax result in increased prices which in turn negative effect household consumption. The value of ECM term is -0.159. This negative value of ECM term indicates that HCEXP (household consumption expenditures) converge to equilibrium.

Above results show that taxes in Pakistan have negative effects on consumption, negative effects on investment and finally negative effects on GDP. These results indicate the negative effects of taxes on various economic activities in Pakistan. Finally we can say that taxation in Pakistan have negative effects on economy. Further empirical analysis is required to explore the reasons behind negative effects of taxes.

\section{Conclusion}

This empirical analysis of taxes has explored negative effects of taxes in economy of Pakistan. Both consumption and investment, that are considered major economic activities, showed negative response against taxes, as a result, overall effects of tax on GDP are also negative. Finally we concluded that taxation in Pakistan have negative effects on aggregate economic activity.

Our findings suggested that taxation in Pakistan should be improved by increasing government expenditures on public services, reducing gap between direct and indirect tax. In order to avoid negative effects of taxation on economy strong policy recommendations by increasing the tax base, increase the number of tax payers, efficient collection of income tax amount, reducing distortions and phasing out exemptions, reducing the compliance costs and government's administrative cost, are required to improve the tax system.

\section{References}

[1] Abdullah, M., \& Kalim, R. (2009). Determinants of food price inflation in Pakistan. In conference of University of Management Sciences, 1-21.

[2] Alm, J., \& S Asmaa, E, G. (2013).Value-added taxation and Consumption. International Tax and Public Finance, 20(1), 105128.

[3] Anastassiou, T., \& Dritsaki, C. (2005). Tax revenues and economic growth: An empirical investigation for greece using causality analysis. Journal of Social Sciences, 1(2), 99-104.

[4] Atif, M., Shahab, S., \& Mahmood, M. T. (2012). The Nexus between Economic Growth, Investment and Taxes: Empirical Evidence from Pakistan. Academic Research, 3(2), 530-537.

[5] Azeem, M. M., Saqi, M., Mushtaq, K., \& Samie, A.(2013). An Empirical Analysis of Tax Rate and Economic Growth Linkages of Pakistan. Pakistan Journal of Life and Social Sciences. 
[6] Charney, A. H. (2010). Public Services Positively Impact Growth: A Review of Taxation and Growth Literature, Arizona Fiscal issue at the University of Arizona. The Karl Eller Center of The College of Business and Public Administration.

[7] Dahlby, E. F. (2012). The impact of tax cuts on economic growth: Evidence from the Canadian provinces. National Tax Journal, 563-594.

[8] Ebiringa, O. T., \& Yadirichukwu, E. (2012). Analysis of Tax Formation and Impact on Economic Growth in Nigeria. International Journal of Accounting and Financial Reporting, 2(2), 367-385.

[9] Economic Survey of Pakistan(Various Issues). Government of Pakistan, Finance Division, Economics Advisor's Wing, Islamabad.

[10] Frank, M. Z., Singh, R., \& Wang, T. Y. (2010). Personal Income Tax and Corporate Investment. Working Paper.

[11] Garner, C. A. (2005). Consumption taxes: Macroeconomic effects and policy issues. Economic Review-Federal Reserve Bank of Kansas City, 90(2), 5-29.

[12] Gupta, R. (2012). Impact of income tax on saving and investment: a case study of assesses in Jammu. Indian Journal of Applied Research, 2(3), 75-77.

[13] Harberger, A. C. (1966). Efficiency effects of taxes on income from capital. in Marian Krzyzaniak. Wayne State University Press, $107-117$.

[14] Inam, M., \& Khan, S. (2008). Pakistan's Taxation System: A Critical Appraisal. Journal of Managerial Sciences, 2(1), 97-127.

[15] Ioan, M., \& Constanti, D. (2010), taxes and economic growth in Romania. A VAR approach. Annales Universitatis Apulensis Series Oeconomica, 13(1), 2011.

[16] Iqbal, N., \& Nawaz, S. (2009). Investment, inflation and economic growth nexus. The Pakistan Development Review, 863-874.

[17] Koester, R. B., \& Kormendi, R. C. (1989). Taxation, Aggregate Activity and Economic Growth: Cross-Country Evidence on Some Supply-Side Hypotheses. Economic Inquiry, 27(3), 367-86.

[18] Lee, Y., \& Gordon, R. H. (2005). Tax structure and economic growth. Journal of Public Economics, 89(5), 1027-1043.

[19] Lescaroux, F., \& Mignon, V. (2008). On the influence of oil prices on economic activity and other macroeconomic and financial variables. OPEC Energy Review, 32(4), 343-380.

[20] Mashkoor,M. Yahya,S. and Ali, A.(2010). Tax revenue and economic growth: An empirical analysis for pakistan. World Applied Sciences Journal, 10(11), 1283-1289.
[21] Miki, B. (2011). The Effect of the VAT Rate Change on Aggregate Consumption and Economic Growth. CJEB Working Paper, no. 297.

[22] Myles, G. D. (2007). Economic Growth and the Role of TaxationAggregate Data (No. 714). OECD Publishing.

[23] Padovano, F., \& Galli, E. (2001). Tax rates and economic growth in the OECD countries. Economic Inquiry, 39(1), 44-57.

[24] Parker, J. A. (1999). The reaction of household consumption to predictable changes in social security taxes. The American Economic Review, 89(4), 959-973.

[25] Phillips, J. M., \& Goss, E. P. (1995). The effect of state and local taxes on economic development: A meta-analysis. Southern Economic Journal, 320-333

[26] Poulson, B. W., \& Kaplan, J. G. (2008). State income taxes and economic growth. Cato J., 28, 53.

[27] Refaqat, S. (2003). Social Incidence of the General Sales Tax in Pakistan (EPub). International Monetary Fund.

[28] Richter, W. (2000). An efficiency analysis of consumption and production taxation with an application to value-added taxation. International Tax and Public Finance, 7, 23-41

[29] Saghir, R., \& Khan, A. (2012). Determinants of public and private investment an empirical study of Pakistan, International Journal of Business and Social Science, 3(4), 183-188.

[30] Schreiber, U., Spengel, C., \& Lammersen, L. (2002). Measuring the impact of taxation on investment and financing decisions. Schmalenbach Business Review (sbr), 54(1), 2-23.

[31] Shahbaz, M., \& Rahman, M. M. (2010). Foreign capital inflowsgrowth nexus and role of domestic financial sector: an ARDL cointegration approach for Pakistan. Journal of Economic Research, 15(3), 207-231.

[32] Stephen,. J., E,. (2009). The Effect Of The Capital Gains Tax Rate On Economic Activity And Total Tax Revenue. The IRET Publication, Capital Gain Series No.1.

[33] Vanoli, M., Daina, E., Salvarani, C., Sabbadini, M. G., Rossi, C. Bacchiani, G., \& Bertolini, G. (2005). Takayasu's arteritis: A study of 104 Italian patients. Arthritis Care \& Research, 53(1), 100-107.

[34] Hand Book of Statistics (2010). State bank of Pakistan, Publications wing, Karachi, Pakistan. 